\title{
Exports of Fisheries in India with special reference to Tuticorin
}

\author{
DR.MS.G.UMA, \\ Associate Professor,Department Of Economics, Fatima College,Madurai - 18.
}

\section{INTRODUCTION}

Fisheries in India are very important economic activity and a flourishing sector with varied resources and potentials. Only after the Indian Independence, has fisheries together with agriculture been recognized as an important sector. India is home to more than 10 percent of the global fish diversity. Presently, the country ranks second in the world in total fish production with an annual fish production of about 9.06 million metric tonnes ${ }^{1}$.

India has 7517 kilometers of marine coastline, 3,827 fishing villages, and 1,914 traditional fish landing centers. India's fresh water resources consist of 195,210 kilometers of rivers and canals, 2.9 million hectares of minor and major reservoirs, 2.4 million hectares of ponds and lakes, and about 0.8 million hectares of flood plain wetlands and water bodies. As of 2010, the marine and freshwater resources offered a combined sustainable catch fishing potential of over 4 million metric tonnes of fish. In addition, India's water and natural resources offer a tenfold growth potential in aquaculture (farm fishing) from 2010 harvest levels of 3.9 million metric tonnes of fish, if India were to adopt fishing knowledge, regulatory reforms, and sustainability policies adopted by China over the last two decades. India is a major supplier of fish in the world. In 2006 the country exported over 600,000 metric tonnes of fish, to some 90 countries, earning over $\$ 1.8$ billion

India's aquaculture production basically can be classified into freshwater and brackish water production. There are 429 Fish Farmers Development Agencies (FFDA) and 39 Brackish water Fish Farmers Development Agencies (BFDAs) for promoting freshwater and coastal aquaculture. Some of the important species cultured in India are the Indian major carps and shrimp. Besides these, ornamental fish culture and seaweed farming, are slowly gaining importance in the aquaculture scenario in the last few years as alternative livelihood supporting sectors as small-scale activities.

\section{STATEMENT OF THE PROBLEM}

Despite of the rapid growth in total fish production, a fish farmers' average annual production in India is only 2 tonnes per person, compared to 172 tonnes in Norway, 72 tonnes in Chile, and 6 tonnes per fisherman in China. Higher productivity, knowledge transfer for sustainable fishing, continued growth in fish production with increase in fish exports have the potential for increasing the living standards of Indian fishermen. As of 2010, fish harvest distribution was difficult within India because of poor rural road infrastructure, lack of cold storage and absence of organized retail in most parts of the country. In 2013, with access to Sri Lankan waters closed after the defeat of the Liberation Tigers of Tamil Eelam, Indian fishers quickly overfished their own waters and production plummeted. Thus, the researcher has undertaken a project on production and exports of fisheries especially from Tuticorin port, Tamil Nadu, India.

\section{Research Objectives:}

1. To analyze the growth of production of fisheries in the study area.

2. To examine the relationship between Production and Value of Exports in Rs as well as US(\$).

\section{REVIEW OF LITERATURE}

Ragupathy Venkatachalam (2005) ${ }^{2}$ in his article the objective of the paper was examined the threat to the substantially of the fisheries in India and in particular in the Gulf of Mannar region. It is widely quoted that the depletion is due to the introduction of trawler fishing techniques, which scrape the bottom of the sea and end up catching juvenile fish. In viewing this problem of over fishing (by the trawlers) as a negative externality to the

\footnotetext{
${ }^{2}$ Ragupathy Venkatachalam., Sustainable Fisheries and Community Management Systems, Paper presented in "Environment and Growth" of the 2nd South Asian Economics Students Meet 2005 at Lahore, Pakistan, Jan28-30, 2005 being organized by the Lahore University of Management Sciences (LUMS). 
traditional fishing community, the best way to internalize the social cost inflicted by the people who over fish is the question that this study attempts to seek the answer for. One of the most commonly practiced techniques to sustain the fisheries resource is the blanket ban on fishing during specific months of the year which is the one practiced in the coastal regions in India. The researcher has attempted to critically evaluate the effectiveness of this method of resource conservation. The researcher has also proposed an alternative model for sustaining the resources, which would be an effective solution for the problem.

Namasivayam (2007) ${ }^{3}$ in his article entitled' India marine Exports; An over view, observed that the marine food export fetches several crores of foreign exchange to our country and provides employment opportunities for people directly and indirectly. To increase the export of marine food products to various countries, the hurdles such as EXIM duties, over tax in the exports is to be taken into consideration with immediate effect.

\section{Limitation:}

- The research study Secondary data source. It is not applicable for macro level study.

- This study focused on Tuticorin district in Tamil Nadu.

- The suggestion applicable for the selected study area not for the universe.

\section{RESEARCH METHODOLOGY:} journals.

The research has been done with the help of Secondary Data from official government websites,

\section{Secondary Data:}

The Data has been Collected for 10 years from 2004-2005 to 2014-15. In order to have a clear cut view on the production and export of Fisheries after Tsunami in Tamil Nadu especially in the study area i.e., Tuticorin.

\section{Hypothesis}

1. There is a positive relationship between Quantity of Fisheries production and value of Production (Cr's).

2. There is a positive relationship between Quantity of Fisheries production and value of Production (\$'s).

\section{Tools for Analysis:}

1. Trend Analysis used to understand the growth of fisheries production from 2004-2005 to 2014-15.

2. Correlation was used to analyse the relationship exist between the Production of fisheries and its value of exports in Indian (Rs) and in US (\$).

\section{Area of study}

Tuticorin, also known as Thoothukudi is a port city and a Municipal Corporation and an industrial city in Thoothukudi district of the Indian state of Tamil Nadu. The city lies in the Coromandel Coast off Bay of Bengal. Thoothukudi is the headquarters of Thoothukudi District. Thoothukudi is known as "Pearl City" due to the pearl fishing carried out in the town. It is a commercial seaport which serves the inland cities of Southern India and is one of the sea gateways of Tamil Nadu. It is also one of the major seaports in India with a history dating back to the 6th century AD.

\section{Research Gap:}

There are many studies have been conducted on the fishermen community their problems, issues in marketing the product, capturing the fishes, Technological advancement, environmental depletion and its effect of marine live hood, difficulties with other country while crossing the border but very few studies were concentrated on the export of fisheries. It is very rare if we take in case of Tamil Nadu and its exports of marine goods. Thus, the researcher concentrated on the production and export of fisheries in Tamil Nadu especially in Tuticorin District. Thus the research gap is being filled

\section{Trend Analysis}

\begin{tabular}{|l|l|}
\hline Year & Quantity in Ton \\
\hline $2004-05$ & 28160 \\
\hline
\end{tabular}

\footnotetext{
${ }^{3}$ Namasivayam, N., Indian Marine Export: An Overview, Southern Economist, Bangalore, 2007, pp.41-42.
} 


\begin{tabular}{|l|l|}
\hline $2005-06$ & 27172 \\
\hline $2006-07$ & 30611 \\
\hline $2007-08$ & 29697 \\
\hline $2008-09$ & 29354 \\
\hline $2009-10$ & 27782 \\
\hline $2010-11$ & 30220 \\
\hline $2011-12$ & 34532 \\
\hline $2012-13$ & 32989 \\
\hline $2013-14$ & 39547 \\
\hline $2014-15$ & 42203 \\
\hline
\end{tabular}

Source: The Marine Exports Authority India

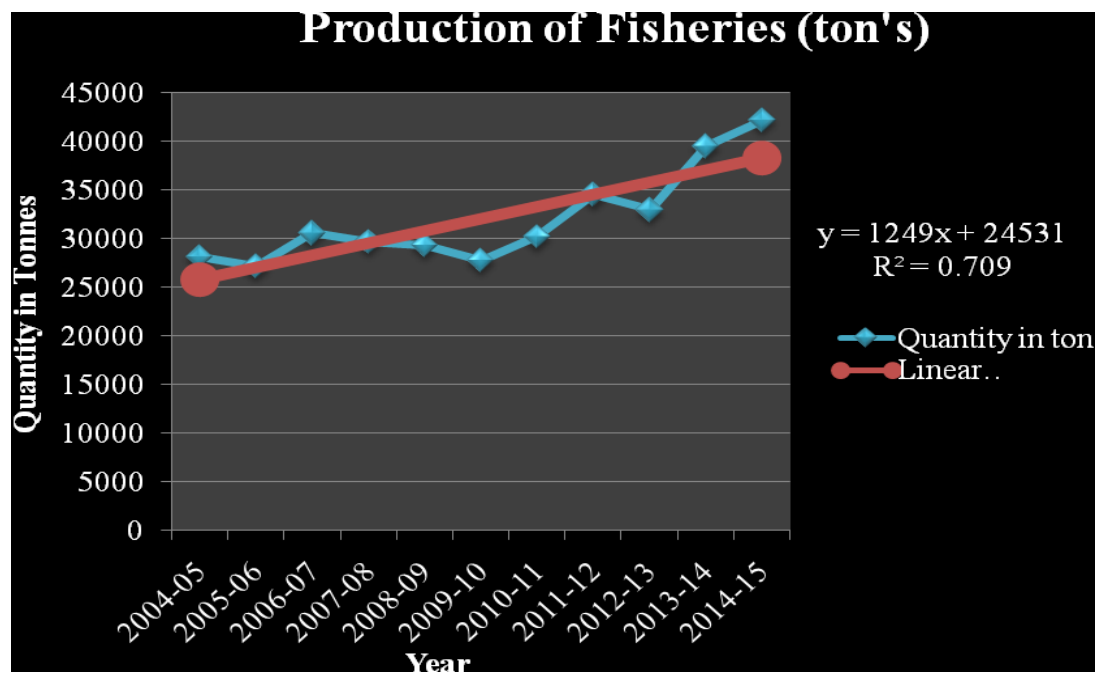

Inference:

The above table shows the production of fisheries in tutuicorin district in Tamil Nadu for the past 10 years i.e., from 2004-05 to 2014-15.After the hit of Tsunami in Tuticorin district the production of Fisheries were drastically reduced. Government took several steps to bring back the normal condition in Tsunami affected areas. After few months the fish production stared and to meet the day to day needs fishermen starts to work hard by capturing the fishes it increases the exports of fishes in the next year i.e. 2006-07. From 2007-08 their was a reduction in exports because of the problems between countries, over fishing, and global recession was also started vigourasly. But India was not affected to the great extent because of the policies followed by the government. So the exports increaded in the year 2010-12. Again it was reduced due to political problems. During 2013-15 the development of Fisherie Industry and Concentration by the government on the fisheries sector specially on Ornamental fish culture and seaweed farming is increasing. The fishes are being grown with the help of artificial materials to increase the production of eggs which lead to increase in fish production it increases the exports of fishiries sector in India.

\section{TESTING OF HYPOTHESIS}

Correlation

\begin{tabular}{|l|l|l|}
\hline & Quantity in ton & Value in Crore \\
\hline Quantity in ton & 1 & \\
\hline Value in Crore & 0.979002214 & 1 \\
\hline
\end{tabular}

Inference: 
Hence, the null hypothesis has been accepted at 0.01 level of significance that there is a positive relationship between Production of Fisheries and Value of Production in Crore.

\section{Correlation:}

\begin{tabular}{|l|l|l|}
\hline & Quantity in ton & US\$ Million \\
\hline Quantity in ton & 1 & \\
\hline US\$ Million & 0.989663821 & 1 \\
\hline
\end{tabular}

\section{Inference:}

Hence, the null hypothesis has been accepted at 0.01 level of significance that there is a positive relationship between Production of Fisheries and Value of Production in Crore.

\section{Suggestion:}

1. Increase the production of fisheries by using organic materials instead of injecting fishes to lay more eggs.

2. Allow the fishes to grow naturally with a specific period of time.

3. Don't use or through plastics, oil spills, petrol leakages in coastal regions it will directly affect lives of fishes and other resources in sea.

4. Fullest utilization of Mechanical Equipements, Financial and other facilities given by the government by the fish farmers.

5. Necessary steps to be taken to explore more new resources like Ornamental fishes, shrimps, Seaweed etc.., in Fresh Water to earn more foreign exchange.

\section{CONCLUSION:}

Even though Tamil Nadu stood $4^{\text {th }}$ all over Indian in the production of Fisheries with 559,360 Metric tonnes. Till the production of Fisheries in India is very less compared to other countries in the world. Hence, the proper attention and care has to be taken by the government, Fisher Folks, Tourists, People residing near coastal area to take a pledge against usage of plastics, petrol, oil based boats for fishing, using chemicals for faster growth of fish, following the restrictions made by the government. Government has to take necessary steps to solve the problems between the countries to protect the fishermen and to have a cordial relationship between other countries. By following these the production of fisheries can be increased. It will automatically increase the production of fishes in the coastal areas rather than the fish growing centers.

\section{Journals:}

\section{REFERENCES:}

[1] Ragupathy Venkatachalam., Sustainable Fisheries and Community Management Systems, Paper presented in "Environment and Growth" of the 2nd South Asian Economics Students Meet 2005 at Lahore, Pakistan, Jan28-30, 2005 being organized by the Lahore University of Management Sciences (LUMS).

[2] Namasivayam, N., Indian Marine Export: An Overview, Southern Economist, Bangalore,

a. 2007, pp.41-42.

[3] http://shodhganga.inflibnet.ac.in/bitstream/10603/14791/8/08_chapter\%202.pdf

[4] http://shodhganga.inflibnet.ac.in/bitstream/10603/61266/13/13_chapter\%207.pdf

[5] http://ijrmbs.com/wp-content/themes/vantage/doc/vol1-issue1/sivanesan.pdf

[6] http://papers.ssrn.com/sol3/papers.cfm?abstract_id=2196700

[7] Websites:

[8] https://en.wikipedia.org/wiki/Fishing_in_India

[9] http://www.fao.org/fishery/countrysector/naso_india/en

[10] http://eprints.cmfri.org.in/2883/1/Article_28.pdf

[11] http://pelagiaresearchlibrary.com/european-journal-of-experimental-biology/vol4-iss4/EJEB-2014-4-4131-135.pdf

[12] http://164.100.150.120/mpeda/marine_products_exports.php\# 